\title{
If They Were Going to Kill My Brother Standing Deer
}

f we are to vent our riotous anger let it be before they try to murder Mumia Abu-Jamal, not after.

-- Michael Parenti, Martin Luther King High School, Berkley, June 25, 1995

We are at a point beyond candle vigils that reflect little besides moral indignation.

-- Ray Luc Levasseur

Think of sister Assata. We don't need another martyr. We need our brother Mumia breathing, smiling, laughing, alive and well among us, talking that talk and writing those words as only he can do it.

-- Standing Deer

If they were going to kill my brother

I would raise him ... rescue him

steal him away from the murderous

thugs of the state.

They don't need his life nohow!

They can't sell it for twice what it's worth

'cause there ain't that much money in the world.

So what for do they want it?!?

He don't mean nothin' no way

'cept to those who love him

and need him

and can't do without him.

I always wonder why we let freedom fighters

rot their lives away in some jail

or go down in a murder for hire plot

rigged by the state.

Folks be marching and hollering

and carrying signs crying his name 
demanding his freedom, but

if signs and words could free him

he woulda been free a long time ago.

This is not about revolution and we don't need

the masses to rise up and wrest away

the means of production

from the criminal class. This is about

our brother's life. His LIFE!

And it only takes a few of us

WHO DON'T WANT HIM DEAD.

There is no magic in a uniform and badge

even if the State, Nation and World Rulers

are behind those symbols

so if somebody wants him free, there he is

over there in that dungeon

guarded by folks who bleed when they're hurt

just like you and me.

Jonathan the man/child had the idea

and the brains

and the courage

he just didn't have the understanding that

the state will throw away

functionaries within their apparatus

as if they were dirty toilet tissue

and never look back.

Frederick Douglass said: "Power concedes nothing

without a demand. It never has and

it never will."

Carlos said: "You do things with bullets

because bullets are real."

It has to start somewhere and sometime,

what better place than here?

What better time than now?

FREE MUMIA ABU-JAMAL!!!! 